\title{
Gynecologic Oncology Group Study 229C: Personal Reflection
}

\author{
Kimberly K. Leslie, MD ${ }^{1,2}$
}

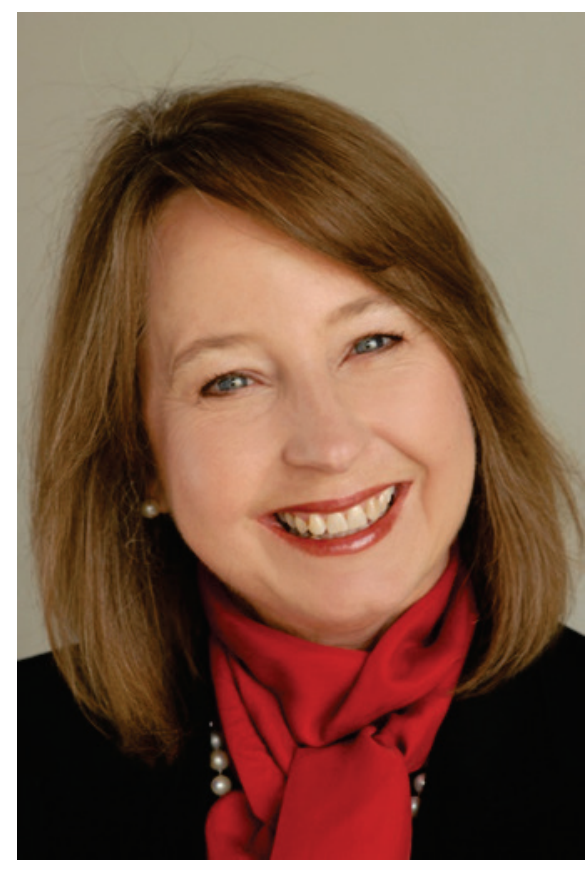

Dr. Leslie is Chair of Obstetrics and Gynecology at the University of lowa. In addition to her clinical and administrative responsibilities, she maintains a productive translational research laboratory.
I heard the statistician say, "The drug does not have sufficient activity to study further in this population." It was my coinvestigator on GOG study 229C, Gefitinib in the Treatment of Advanced and Recurrent Endometrial Cancer (see related extended abstract in this issue ${ }^{*}$ ), calling from Roswell Park in Buffalo. He had just completed the analysis of data from 26 women treated on our study - a study which had been five years in the making from concept to clinical trial.

These are the most damning words a clinical investigator can hear. I thought back to the beginning, when our preclinical studies indicated a new molecular agent, gefitinib, a member of a class of small molecules which blocks the epidermal growth factor receptor, could kill cancer cells in the laboratory. I sold the idea to use the drug for patients with endometrial cancer to the $\mathrm{NIH}$ and the pharmaceutical company based upon this rosy picture of activity. I thought about the seed money we used to initiate the trial, which had come from the family of a patient who had died of the disease, Barbara Beach. The family had so hoped that gefitinib would do for others what previous treatments failed

${ }^{1}$ The Department of Obstetrics and Gynecology and ${ }^{2}$ Holden Comprehensive Cancer Center, Roy J. and Lucille A. Carver College of Medicine, The University of lowa, lowa City, Iowa, USA.

Please cite this paper as: Leslie KK. Gynecologic Oncology Group Study 229C: Personal Reflection. Proc Obstet Gynecol. 2013;3(3 Suppl):Article 2 [ 2 p.]. Available from: http://ir.uiowa.edu/pog/. Free full text article.

Corresponding author: Kimberly K. Leslie, Department of Obstetrics and Gynecology, University of lowa, 200 Hawkins Drive, lowa City, IA 42242. kimberly-leslie@uiowa.edu

This is an Open Access article distributed under the terms of the Creative Commons Attribution 3.0 Unported License (http://creativecommons.org/licenses/by/3.0), which permits unrestricted use, distribution, and reproduction in any medium, provided the original work is properly cited. 
to do for their mother. They donated $\$ 250,000.00$ in her honor to support this trial!

Then I thought about the patients - 26 women who had failed all other therapies and hoped against hope to find a cure in gefitinib. After all, hadn't we shown them the laboratory data? Hadn't we believed ourselves that we had found a breakthrough agent? As the lead investigator, I was blinded to their names and their clinical outcomes until the very end of the study....I knew them only as numbers, like G17982, etc. I knew them only as the blocks of tumor tissues sent to my laboratory to study. The assays had appeared promising on the tissues - why didn't it work in the patients??

I said to my colleague, "I can't believe that gefitinib didn't help anyone - it just doesn't seem possible given our preliminary data." He replied, "What I meant to say is that the drug does not have more activity than standard chemotherapy. That doesn't necessarily mean that no one benefited. Let me see...... oh yes, I meant to mention that patient G55394 had a complete response."

"You said a complete response? You mean she is cured? What does that really mean if the drug is not active?"

"She had a recurrent tumor nodule which has now disappeared," he said in a matter of fact statistical tone. "But that doesn't guarantee that it was as a result of the drug, you know."

I often think of Mrs. G55394 and hope she enjoyed the years she lived after taking gefitinib - I hope she enjoyed her family and all of the important things in life. I will never know her personally, but she is a big part of my life even now. Cancer will never be cured by a single drug; I know that now as does everybody in the field. Nevertheless, some agents work very well for unique tumors, and it is now our goal to understand why.

*See "A phase II evaluation of gefitinib in the treatment of persistent or recurrent endometrial cancer: A Gynecologic Oncology Group study. Proceedings in Obstetrics and Gynecology, 2013; 3(3 Suppl):5." An abstract of Leslie KK, Sill MW, Fischer E, Darcy KM, Mannel RS, Tewari KS, Hanjani $P$, Wilken JA, Baron AT, Godwin AK, Schilder RJ, Singh $M$, Maihle NJ. A phase II evaluation of gefitinib in the treatment of persistent or recurrent endometrial cancer: a Gynecologic Oncology Group study. Gynecol Oncol. 2013 Jun;129(3):486-94. doi: 10.1016/j.ygyno.2013.02.019. Epub 2013 Feb 21. PubMed PMID: 23438670 